\title{
Collective Vertigo
}

\section{Roger Caillois" "Théorie de la Fête" Toward Contemporary Music Festivals in Poland and Hungary}

\author{
Waldemar Kuligowski \\ Department of Ethnology and Cultural Anthropology \\ Adam Mickiewicz University, Poznan, Poland
}

\begin{abstract}
This paper is an attempt to apply Roger Caillois' "théorie de la fête" to the contemporary music festivals in Poland and Hungary. The French ethnologist suggested that modernity does not provide the opportunity for collective vertigo, marginalizes the festival, and transforms it into a possibility that is difficult to achieve. Accordingto the results of my ethnographic fieldwork, the festival is a place of rest, fun, elation, rewarding belonging to a community, or even freedom at different levels. For many participants, it is a holiday in its purest form; a festival whose subject is music, but whose purpose is mental rest. In this context, the concept of festivalization should be redefined. In the analyzed cases (Jarocin Festival, OFF Festival, and O.Z.O.R.A. Festival), festivalization is not reduced to specific, collective forms of consumption; it also means the possibility of creating specific space-times of rest and freedom.
\end{abstract}

Keywords: festival, Roger Caillois, music, festivalization, Hungary, Poland, audience

\section{INTRODUCTION}

It goes without saying that festivals are one of the more interesting elements of European culture and a manifestation of its traditions (BURKe 2009; Eliade 1957; FalaSSI 1987). As noted by Swedish ethnologist Owe Rönström (2011), "festival began to be used as a generic term for a large array of celebrations that carry few or no religious connotations (...) The world has been festivalized." This process contains different threads. On the one hand, Rönström continues, homogeneous festival events carried out by people with similar cultural competencies and similar strategies of reception or consumption continue to exist. These types of festivals, however, are a minority. Contemporary fairs, meetings, days, fetes and celebrations - often labeled as festivals - consist of taking walks, eating, drinking, smoking, and small talk. It is about being on holiday, outside work, and spending leisure time. This process has transformed the festival into a specific popular meeting place addressed to all recipients, offering every type of music and a huge variety of non-musical attractions and activities. 
Rönström underscores the link between the festival industry and the tourism industry. After all, festivals create attractions for tourists and the tourism industry provides consumers with these attractions. This feedback loop results in a huge number of festivals that attract people to countless places around the world, especially during the holiday season. It requires the connection of festival locations with a network of motorways or airports, which are used by both the artists and the audience. The complex web of meanings and functions of modern festivals means that they can be seen as a "vessel of meaning" (a term coined by the Norwegian social anthropologist Fredrik Barth). Like other phenomena of the postmodern and capitalist world, festivals have a dichotomous structure.

Rönström's statements are accurate. Even a cursory look at a national, regional and even a local calendar confirms that festivals have become a prominent feature of cultural life in today's social space. Festivals are organized by public institutions, local governments and non-governmental organizations. Cities adapt their investment plans to them (e.g. by speeding up the construction of access roads), as well as class schedules in schools and universities (as was the case in Polish and Ukrainian cities which hosted the matches of the European Football Championship in 2012), and adjust their regulation of road traffic, trade, marketing, the sale of alcohol, etc. Financially, organizationally and culturally speaking, the festival has ultimately become a kind of autonomous institutional entity (RichardS - PALMER 2010). George Steiner suggests that the effect of this process is a rapid increase of festivals, as well as the organizing of 'festivals of festivals', the number of which has reached the point of absurdity (STEINER 1996).

\section{THE FESTIVALIZATION SYNDROME}

In the 1990s, the concept of "festivalization" arose in relation to processes in the autonomization of festivals and their hegemony in cultural policy, It was introduced by the German sociologists Hartmut Häußermann and Walter Siebel in the 1993 article "Die Politik der Festivalisierung und die Festivalisierung der Politik", which concerned practicing "festivalization policy" and "politics through festivals". The concept itself was used in the context of "festivalization of urban policy". The authors refer to major sports and cultural undertakings, which were so-called catalysts of urban development in many European countries. In this context, they invoke consecutive Expos (Vancouver 1986, Seville 1992), summer Olympic Games (Munich 1972, Barcelona 1992), Universiades (Sheffield 1991), and the FIFA World Championship (Italy 1990). Häußermann and Siebel claim that in all these cases, urban policy, and especially urban planning policy, was instrumentalized, and subordinated to these single, gigantic events. The concept of "doing politics through festivals" correlated with to the idea of the city as a stage, popular among urban planners in the 1970s: the festival is dominant; it subordinates all other ideas and initiatives, resulting in expensive and ad hoc designed spaces (legal, financial, infrastructural, habitual), created mainly for tourists and the business class.

Häußermann and Siebel's original concept was later repeatedly redefined (LAVILLE 2014; STEINBRINKA et al. 2011). P. Louis van Elderen, using a slightly different formula, stated that festivalization consists of "temporary transformation of a place into symbolic space in which the public domain is claimed for particular forms of consumption" (VAN ELDEREN 1997). Such conceived festivalization began to combine previously 
separate spheres: food and shopping, education and recreation. As a result of progressive homogenization, distinguishing between consumption, entertainment and education became very difficult within the logic of festivalization. Mumbai and Singapore successfully organize "shopping festivals", and in many other cities such forms of boosterism and festivalization are practiced as "edutainment" and "shop-a-tainment" (MalczyK 2010; Richards - Palmer 2010).

In this light, many researchers argue that there exists a crisis of the model of urban cultural policy: "It is important to acknowledge that festivalization only becomes a possibility with the realization of the 'world-class' city: global in outlook, investor'friendly' and a national hub for business; a site with political profile and cultural cachet, and a destination favored by tourists" (EISENHAUER et al. 2014:40). Festivals are often strategically conceived with the purpose of promoting a "distinctive city" (JOHANSSON KociaTKIEWICZ 2011:18).

The perspective of classic anthropology was significantly different. In early anthropological studies, the festival was treated as form similar to a ritual framed by inverted and temporary abnormal reality (DURKHEIM 1912; MAUSs 1906). In this view, many anthropologists observed how the norms and rules of everyday life were suspended during festival time. In the study of "primitive" or tribal festivals, situations of excess, disorder and temporary chaos have been interpreted in relation to communities' mythical pasts. Key contributions to the anthropological field included Arnold van Gennep's (1960) idea regarding rites of passage, and Victor Turner's (1969) concepts of liminality, anti-structure and communitas. On the other hand, Jean Duvignaud argued that the most classic analysis of festivals goes back to Émile Durkheim, who distinguished between the sacred and profane, writing about "collective effervescence" as the supreme moment of the solidarity of collective consciousness (Duvignaud 1976:13).

\section{CAILLOIS" "THEORY OF FESTIVAL"}

I would like to place my analysis in a slightly different context. Certain findings of the French anthropologist and philosopher Roger Caillois are, I think, adequate. I have in mind views from two of his works: L'Homme et le sacré from 1939 and, to a lesser degree, Les Jeux et les hommes: le masque et le vertige from 1958. In these texts, Caillois suggested the original "theory of festival", which can also be applied to the analysis of modern festivals (CAILlors 2001). In my opinion, Caillois' idea of the festival is currently realized in the midst of multi-day music festivals. In this article, I use the concept of the festival in relation to contemporary, repeated practices of collective, multi-day gatherings in one place with the aim of experiencing music. I treat the concept of the holiday, however, as a very general category, also adequate in relation to sacred rituals.

Caillois was a French anthropologist, sociologist and literary critic. He studied at the École Pratique des Hautes Études, where he came into contact with famous thinkers such as Marcel Mauss and Georges Dumèzil. Caillois published extensively in a variety of fields e.g. comparative mythology, the sociology of religion, theory of play and games, and even the evolution of the detective story. He was also co-founder (along with Georges Bataille and Michel Leiris) of the Le Collège de Sociologie (Hollier 1979) and editor of Diogenes, an interdisciplinary academic journal founded by UNESCO. The 
first edition of L'Homme et le sacré was published in 1939 by Presses Universitaires de France. The second, revised version was issued in 1946 by Gallimard. Lucian Febvre, French historian and co-creator of the Annales School, wrote in his review of L'Homme et le sacré that it is a small but fantastic book, containing a clever and clear theoretical proposition (1951).

In his Théorie de la fête, Caillois appealed to Émile Durhheim's opposition of the sacred-profane and Marcel Mauss' descriptions of tribal fête. His concept assumes that the festival is universal in nature and constitutes an important element of all cultures. Caillois associated the festival with the existence of a mythical space-time, in which the festival was to act as a catalyst for the rebirth of the world, recovering its vitality and power. Seen as a return to the sacred, the festival revealed and updated the differences between the secular and the sacred. Referring to many examples - Inuit winter festivals, the Kwakiutl potlatch, Indigenous Australian and New-Guinean rituals, remittances from the Vedas and the rules of Chinese culture - Caillois connected the festival with the sphere of the sacred, religious ritual, and the tribal life cycle.

The most interesting aspects of his description of holidays, however, concern social practices. Caillois defines a holiday/festival in terms of "collective euphoria and vertigo" (2001:97), a "paroxysm of society, purifying and renewing it simultaneously" (2001:125). To emphasize the uniqueness of the event, he created a string of oppositions distinguishing everyday life from holidays: "dual continuity/intermittent explosion", "daily repetition of the same material preoccupations/powerful inspiration", "tranquil labor/fever of climatic moments", "social dispersion/social concentration" (2001:99). The clear distinction from the ordinary and the everyday is additionally reinforced by other holiday practices. Caillois states that during the holiday "normal" rules are suspended, and "excess constantly accompanies the festival" (2001:101). Freedom of manners is recommended, and "dietary and sexual sacrilege" (2001:116), "forbidden and extravagant behavior" as well as "contrary acts" (2001:122) are accepted. Caillois argues that the holiday "connotes a large conglomeration of moving and boisterous people. These massed gatherings eminently favor the creation and contagion of an exalted state that exhausts itself in cries and movement" (2001:97). Participants share the feeling of elation expressed through spontaneous shouts, gestures and reflexes.

Although Théorie de la fête refers primarily to tribal societies, Caillois pointed to some of its elements also being present in contemporary (urbanized and industrialized) culture. Carnival cycles, get-togethers, libations, and even rural wakes used to be a holiday. Currently, it is difficult to find a time dedicated to holidays, which would be characterized by collective bewilderment and exultation. One of the examples he analyzed was vacation time. Caillois saw this as a kind of extension of the holiday. Another relevant example was the category of the "Traveling Fair" (2001b). I will refer to this example below. However, according to the French researcher, none of these examples fully realized the idea of the holiday: "The festival is then succeeded by the vacation (...) it is always a time of free activity, of interruption in the pattern of work, but it is a phase of relaxation, not paroxysm" (CAILLOIS 2001:127). In summary, Caillois was convinced that modernity does not provide the opportunity for collective daze; it marginalizes the holiday and transforms it into a possibility that is difficult to achieve. 


\section{THE FESTIVAL AS A FIELDWORK SITE}

I conducted ethnographic fieldwork at three outdoor music festivals: the Jarocin Festival and the Off Festival in Poland, and the O.Z.O.R.A. in Hungary. Each has its own characteristics and history; they share, however, music as the main medium attracting several thousand people for a few summer days in one particular place.

The Jarocin festival, a rock music event launched in 1980, is the oldest among them. The city of Jarocin is situated in the rural part of the Greater Poland region in western Poland and has around 25 thousand inhabitants. During the 1980s, the festival was a cultural sensation - the biggest rock festival not only in Poland, but also in the entire Eastern Bloc. Every year, it attracted several thousand people, who could demonstrate sub-cultural values, dress and behavior for several days. The festival took place, of course, with the consent of the Socialist government, which did not fully understand its liberating potential. Surveillance of the audience, led by the secret service, brought caricatured effects in the form of reports describing sub-cultural groups akin to naive descriptions of exotic tribes (LesIAKOWSKI et al. 2004). The name of the festival quickly became a symbol of freedom and attitudes alternative to Socialist ideology. The transformation that began in 1989 redefined the meaning of the festival. The organizers first tried to change its format in the vein of other commercial festivals, but in the face of street riots and permanent conflicts between the audience and the police, the festival was held for the last time in 1994. It was reactivated in 2005 and currently seeks to connect with its former importance and status as a "mecca of sub-cultures" (KULIGOWsKi 2015). The festival draws audiences from all over Poland.

The OFF Festival has existed since 2006 and is organized by renowned Polish musician Artur Rojek. It is now held in Katowice, an agglomeration of more than 300 thousand inhabitants which used to be the former industrial center of Silesia. In the years 20062009, the festival was held in the nearby Silesian city of Myslowice, whose authorities no longer wanted to support it financially. The main premise of the festival is to present international alternative music, as well as little-known performers, often operating outside of the mainstream. OFF quickly gained wide recognition in Poland, but also among music critics, who awarded it with the European Festival Award in 2012. Stereotypically, the OFF Festival is associated with hipster attitudes and practices. Its audiences come from not only Poland, but also other neighboring countries (Germany, the Czech Republic, Slovakia).

The O.Z.O.R.A. Festival has been organized since 2004 in the buildings of what used to be a farm in the central part of Hungary, in a village of the same name (Ozora). However, its origins date back to 1999 and involve a total eclipse of the sun, which was experienced by 20,000 people to the accompaniment of psytrance music and its many genres (ST. JoHN 2010:1-17). Today, the festival attracts fans of psytrance music, offering them all-day performances, yoga and meditation practice, lessons in Capoeira, Pilates, Aikido, Tai Chi, Chi Kung, lectures on naturopathy, culinary traditions, spiritual wisdom and even festivalization (led by the author). It should be noted that organizationally and financially O.Z.O.R.A. relies on the activities of people from outside of Hungary, namely post-hippie communities from the Indian Goa and the USA. The festival is stereotypically associated with the availability of drugs and widespread nudity, and has been dubbed the "Hungarian Woodstock". The audience of O.Z.O.R.A. is in a large part international (mainly from Western Europe). 
Given the stereotypical images of these festivals, they are associated with different groups: Jarocin with punks, OFF with hipsters and O.Z.O.R.A with neo-hippies. These images are created by media reports (television, newspapers, websites) as well as by the organizers themselves. There is, in this case, a two-way flow of images and symbols that form as a result the public image of the festivals. It should be noted that the audience in Jarocin comes from Poland, the audience in Katowice from Central Europe, and the audience in Ozora from all over Europe.

I conducted ethnographic research with a group of associates at all of these festivals in 2015, using classic methods in the form of interviews (qualitative data) and surveys (quantitative data), as well as photos, video recordings and elements of field recording. It was not my first experience doing research work at festivals - previously, I had also conducted research at the Berlin Love Parades (practicing the idea of love) (KULIGOWSKI 2004), the Serbian Guča Trumpet Festival (practicing nationalism) (KULIGOwsKi 2014), and the Canarian carnival in Santa Cruz de Tenerife (practicing tradition) (KuLIGowsKI 2016). I would like to emphasis that ethnographic fieldwork during the festivals comprises specific experiences. According to Alice O'Grady (2013), the researcher should be open to "embodied knowledge" and an "auto-ethnographic flow". In this case, the classic formula of participant observation did not work. I would argue that the anthropologist can no longer be seen as an observer recording cultural or social facts and processes but must be seen as "an active, situated participant in the construction of account and representations" (TURNER 2000:51). In relation to ethnographic fieldwork, it is claimed that all positionings and all perspectives are partial; every description and interpretation are partial truth (CLIFFORD 1986:7).

Consequently, in the course of my fieldwork, I was rather an "emotionally engaged" anthropologist than a "coolly dispassionate observer" (TEDLOCK 1992:xiii). I practiced permanent "collaboration" with music, dance, giant crowds of people, different sounds, colors, and smells. I was in flow and, perhaps too many times, I flowed. On the other hand, many times I experienced "frustrating reality" because "I often find myself anxious and edgy at the point where those around me were experiencing the opposite feelings of immersion, pleasure and play" (O'GRADY 2013:31). For this reason, I tried to used the "horizontal method of research" (THOMPSON 2009:134) in which the researcher is situated alongside the festival participant and the gap (or "frustrating reality") between me and my collaborators is diminished.

From my perspective, in the context of the festivalization phenomenon, the commercialization of festivals and their domination of political culture, an important problem is the perspective of their audiences. I confined my ethnographic research on festival audiences to several topics, amongst which the motivation for festival participation had its own place. I spoke with men and women about why they participated in a specific festival and why they had decided to spend their money, energy and time on it. Participation in multi-day music festivals requires financial, logistical and organizational preparation. University and school students planned their holidays according to festival dates, as did professionals. Sometimes individuals performed this coordination only for themselves, but normally groups of friends or family coordinated their festival attendance together. In most cases, not only the price of the ticket or festival pass were taken into account, but also the cost of transport, accommodation, food, souvenirs etc. Participation in a multiday music festival was not a spontaneous decision, but was rather undertaken well ahead 
of time and thoroughly planned. Sometimes a trip to a summer music festival was treated as the focal point of holidays upon which other plans were made. The motivations behind a specific individual's decision to participate in a festival are, in my opinion, crucial in the attempt to describe and understand their meaning.

Fieldwork during festivals entails several important consequences: (1) research is carried out within only a few days (2) the research is conducted in the presence of many people; (3) the context of the research includes many practices, such as listening to music, being in a group of friends, spontaneous music-making, eating, drinking and resting. All these factors surely influence the course of research and its results (e.g. not being able to verify some information, or not being able to observe my interlocutors in situations outside of the festival). On the other hand, the circumstances of the festival create a specific type of relationship, more spontaneous and open. One of the guiding principles is honesty and openness in expressing your views and talking about yourself. From the point of view of the researcher, this is extremely valuable. The aforementioned festival situation is based on the principle of cultural intimacy (HERZFELD 1997), which becomes tangible in the form of a temporary community. It is significant that the participants of festivals themselves feel and express the need for such a community:

\footnotetext{
"There is a nice connection between people at festivals. The point is that I always leave Jarocin richer by at least a few good friends. And to a large extent I think that is most important. The music comes next." (Darek, 47, Jarocin)

"What does the festival give me? I think it's this feeling that I'm in a crowd - a community that is standing or dancing and listening to music and having great fun." (Janek, 19, Jarocin)
}

An examination of the festival audience gives one the opportunity to explore a diverse realm of values. During a festival, morality, love, friendship, the meaning of life - things that are rather hard to talk about in other circumstances - become natural themes. As suggested by Simon Frith, music "has been an important way in which we have learned to understand ourselves as historical, ethnic, class-bound, gendered, national subjects. This has had conservative effects (primarily through nostalgia) as well as liberating ones. What music does (all music) is put into play a sense of identity that may or may not fit the way we are placed by other social forces" (FRITH 1998:276-277). As I have mentioned, in this article I will focus on the motives that induce people to participate in festivals. Is it a kind of longing, perhaps unconscious, for the holiday as understood by Caillois? Or is it rather a specific type of vacation, without the "paroxysm", yet with elements of freedom and escape from the routine of everyday life?

\section{FROM VACATION TO FREEDOM}

Each participant of a music festival can certainly identify with Caillois' detailed description: "They are separated in space by porticoes, hedges, ramps, luminous signs, posts, flags, and all kinds of decorations that are visible from a distance and which demarcate the boundaries of a consecrated universe. In fact, once the frontier is crossed, one finds himself in a world that is peculiarly more crowded than that of ordinary life. It is a world of excited and noisy throngs, a debauch of color and light, of ceaseless and exhausting motion to the point of 


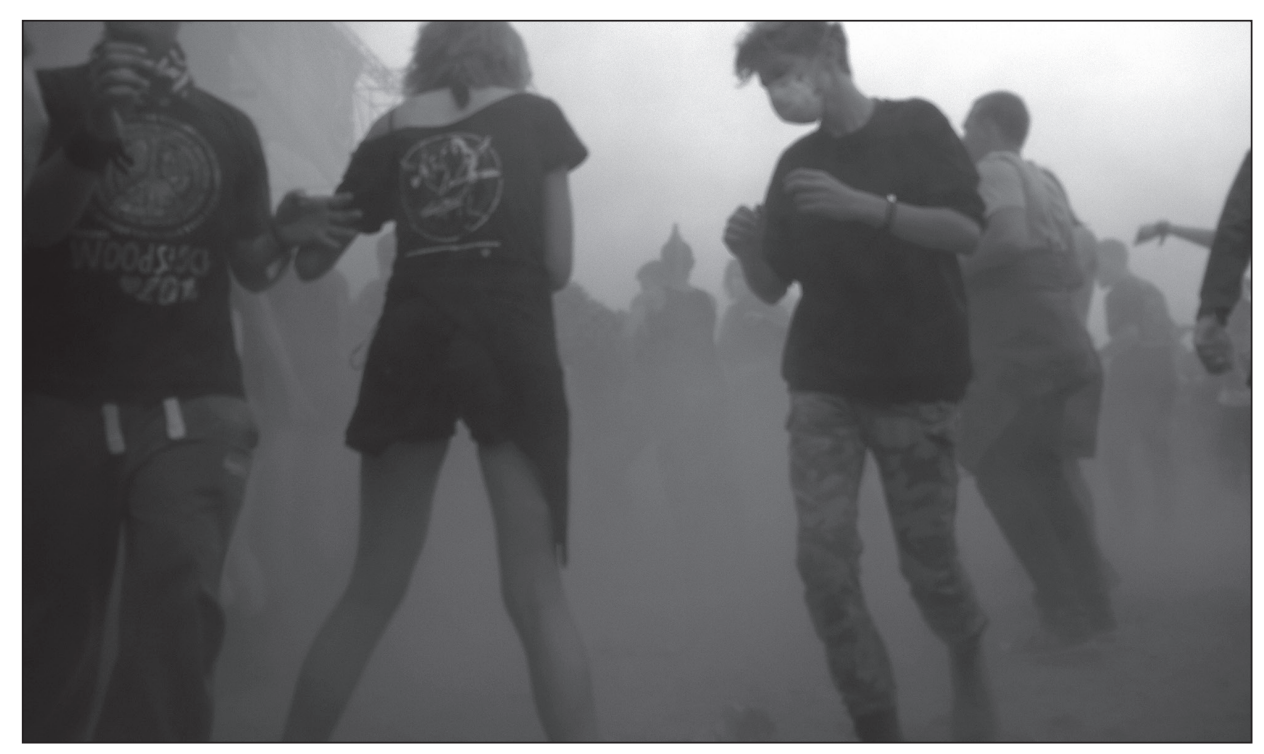

Figure 1. Jarocin Festival, Jarocin, Poland. (Photo by: Waldemar Kuligowski, July 2015)

satiety, in which one may easily accost others or try to attract attention to oneself and which is conducive to freedom, familiarity, boastfulness, and debonair impudence. All this adds a peculiar atmosphere to the general animation" (CAILLOIs 2001:33). Caillois described in this way the separate space of the Traveling Fair. Nothing stands in the way of applying this description to festival towns, which are, despite some differences, similar to each other and repetitive in many of their elements. This pattern is also implemented at festivals in Jarocin, Katowice and Ozora. In each of these places, the everyday is beyond the boarder built from gates, flags and lights. The visual aspects were visually enriched especially at O.Z.O.R.A. Participants greeted a huge gate with the words "Welcome to Paradise". The festival zone was full of wooden figures, masks, fluorescent paintings, spatial installations etc. Many people told about "psychedelic space": "This is amazing part of nature. Here music is always. And everything is lit up." (Hana, 23 years old, O.Z.O.R.A.)

In Alfred Gell's (1998) vocabulary, these were "agents" of the festival's atmosphere, message and values. Many participants treated them as very important symbols or even spiritual "totems"; they were also tools to create an effect being "on edge of the real" (as Yemanja wrote in the festival newspaper "The Ozorian Prophet").

The motivations of the audiences studied in the aforementioned three locations are similar. Regardless of their age, gender and place of residence (country, city size), what dominates is a longing for rest, relaxation and detachment from everyday life. Here are some typical comments:

"I come to here to de-stress, to 'recharge my batteries' and then return to the humdrum reality of struggling for existence. This is how I treat it. I knew long before that I was going, and I only checked which bands were playing here three days before I left." (Darek, 43 years old, Jarocin)

"I come to the festival on Thursday, I leave on Monday, leaving behind my job, Warsaw, the city, traffic jams, newspapers, television, the Internet, and I don't care about anything. I am 


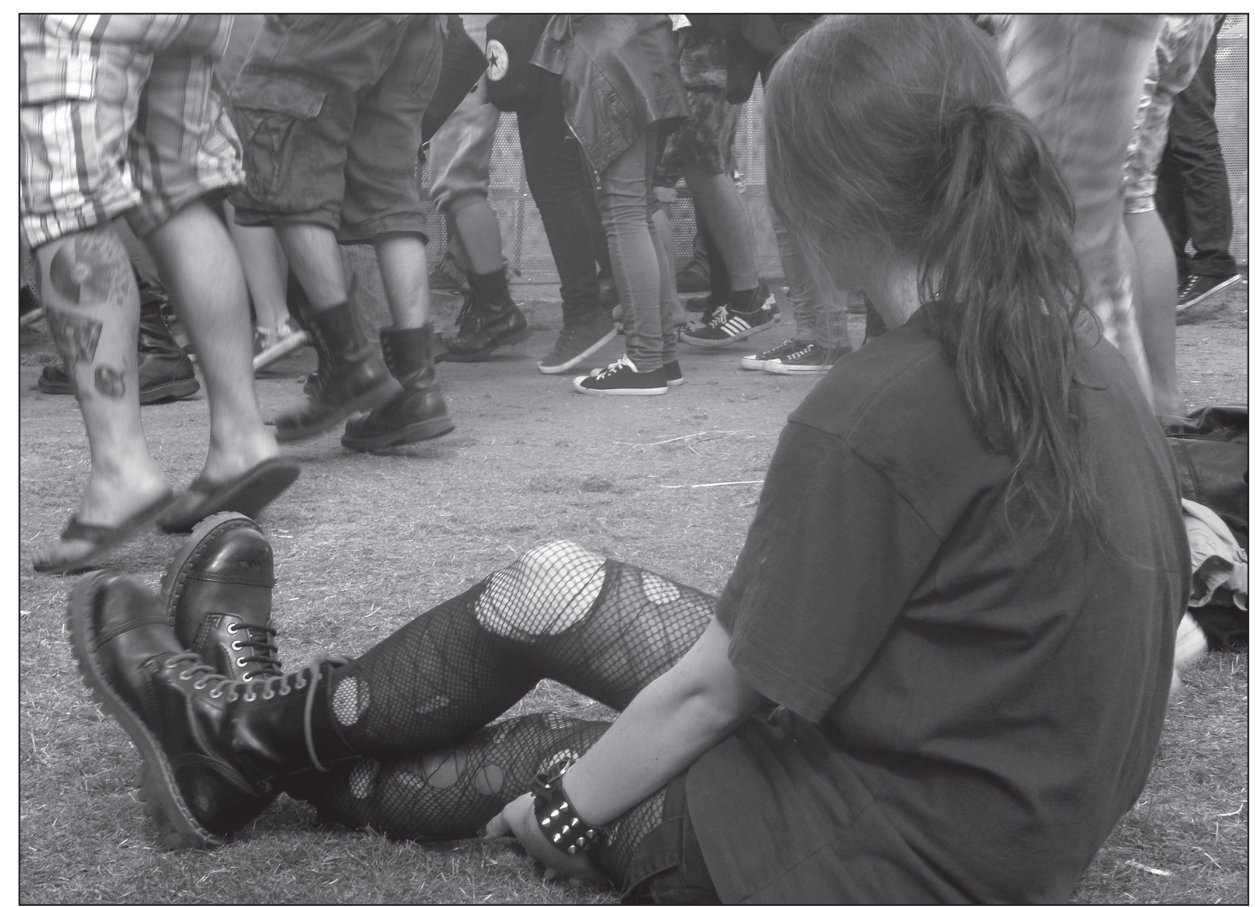

Figure 2. Jarocin Festival, Jarocin, Poland. (Photo by: Waldemar Kuligowski, July 2015)

alienated from life and all I do is have great fun. I'm in a great mood. It is the most important thing - it's the essence of the festival." (Rafał, 42 years old, Jarocin)

"Well, there is such a fun atmosphere all the time, you can really fool around, not doing anyone harm. There is also this freedom; you can walk in slippers all the time. That is a value in itself, for sure. Usually the weather is nice too, and the festival happens to take place in a rather charming place.” (Kuba, 25 years old, OFF)

In this context, the music festival functions like a vacation, or a form of leisure. It is a holiday destination with an unusual and extraordinary program: instead of a hotel and tourist attractions, there is the small festival town and music. An additional advantage could also be a "charming place". What dominates - similarly to a holiday - is a relaxed atmosphere and a lack of haste, a poignant example of which is the ability to "walk in slippers all the time". The festival audience is made up in a large part of those who seek pleasure and satisfaction, "sensation gatherers", as described by Zygmunt Bauman (1993). These values are provided to them by the festival line-up as well as the festival infrastructure: sophisticated dishes in the food court, comfortable accommodation, the possibility to use services, such as a barber, massage or a tattoo parlor, access to additional cultural activities (meetings with writers, exhibitions, film screenings, panel discussions, lectures, etc.).

Detachment from everyday life is also expressed through behavior and dress. In Jarocin, there are people, mainly young men, with spiky hair, which is referred to as a "Mohawk" (Irokez in Polish). These hairstyles are prepared especially for the festival; they 


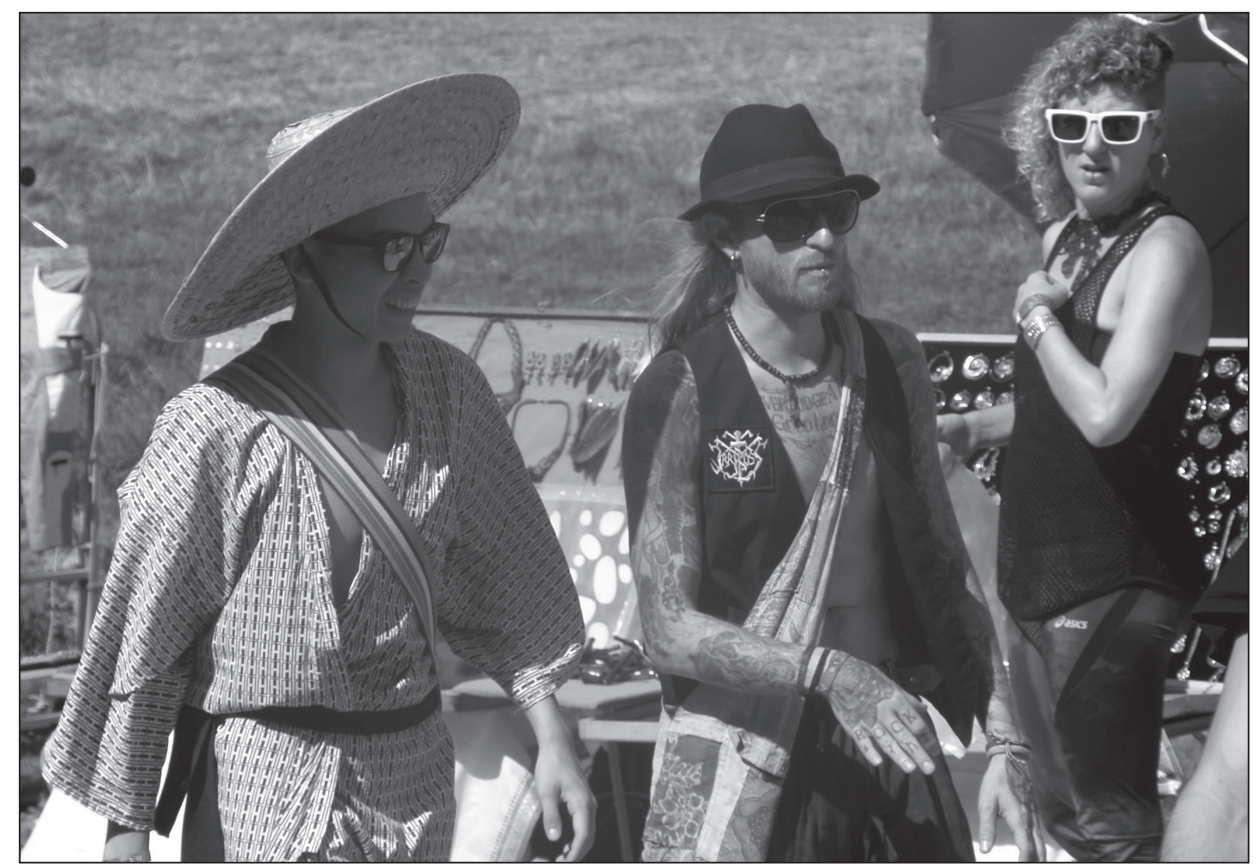

Figure 3. O.Z.O.R.A. Festival, Ozora, Hungary. (Photo by: Waldemar Kuligowski, August 2015)

are not worn either at work or school. Another attribute of the festival are heavy, leather boots ("glany" in Polish slang), once produced for the military, currently purchased in specialized shops. The quintessence of participating in the Jarocin Festival is dancing the "pogo". This spontaneous dance, involving bouncing off other people, jumping up while lifting your knees, is accompanied by very fast music (Figures 1-2). In Katowice, the dominant dress code consists of fancy headgear (hats, berets, scarves) and t-shirts with significant symbols or inscriptions. Surely this is not how the majority of the OFF festival participants dress every day. The emphasis on stylization is so strong that even one of the students working with me changed her hairstyle in the salon at the festival. Ozora, in turn, attracts people fond of "ethno" and "tribal" fashion (Figures 3-5). Feathers in the hair, necklaces with animal tusks, jewelry made of stones and wood, colored trousers and huge tattoos inspired by ethnic designs (mainly Native American and Maori) are the main elements of the festival style. The most prized practice made possible through participation in the O.Z.O.R.A. Festival are the many hours of dancing to the music played by the changing DJs. The often repeated opinion is that the dance - performed alone, often with closed eyes - allows one to completely free oneself from everyday life.

Another important motif for the festival turned out to be freedom. Many participants understand freedom not only in the terms of escape from work, routine and responsibilities. Rather, they speak about a state of mind:

"I feel pure freedom here. I can feel the positive energy of the people, music and place. I can get away from everything negative. It’s great!” (Krista, 32 years old, O.Z.O.R.A.) 


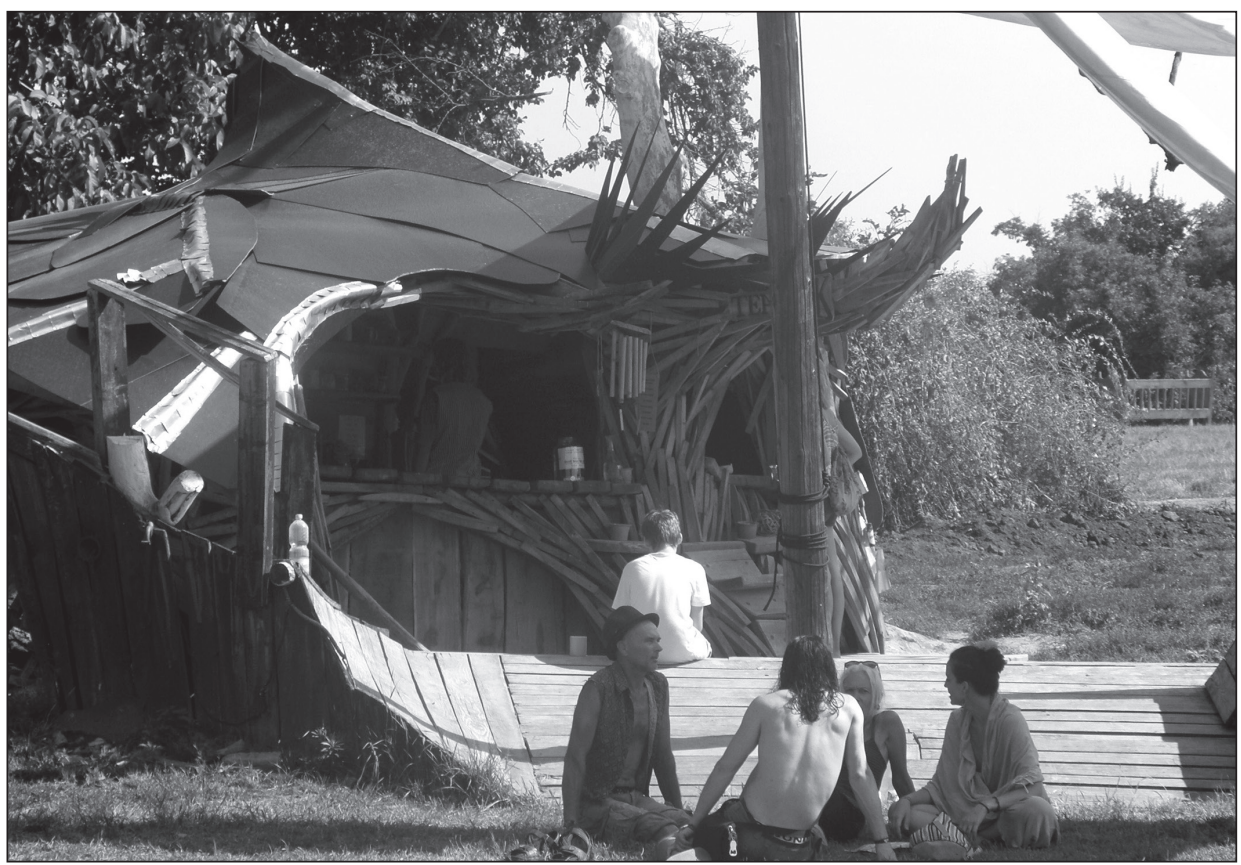

Figure 4. O.Z.O.R.A. Festival, Ozora, Hungary. (Photo by: Waldemar Kuligowski, August 2015)

"I was just thinking that, yes. I just feel free here, because it's as if problems disappear here. I function differently here. I really feel free here. It is so... I feel a bit silly about it. Because it's as if very little is needed, and exactly... I do not know how to understand it, but yes." (Ania, 32 years old, OFF)

The audience at each of the studied festivals looks for freedom in several different areas: politics, art and spirituality. In Jarocin, freedom is associated primarily with the possibility of expressing political opposition, which is closely associated with the image of the festival created in the 1980s. The role of the former state police has been taken over by security guards from a private company. Their work is observed and commented upon. Each instance of behavior by employees of the security company which could be interpreted as violence or a restriction on the freedom of the participants is immediately challenged. Moreover, the audience spontaneously reacts to the statements made by performers which relate to political issues or are a commentary on current events. The old editions of the festival are often mentioned, as are punks' clashes with the police and the problems performers had with censorship. This context gives rise to the statement that the modern editions of Jarocin Festival after 2005 "are not the same as before", that the festival "died" and became similar to other "ordinary" festivals. Festival newspapers, however, are full of references to punk aesthetics, and the city center boasts a statue of a leather boot ("glan"), which clearly indicates which profile is desired by the festival's organizers. Its uniqueness is supposed to grow out of its sub-cultural past.

In Katowice, freedom is invested mainly in the sphere of music and its reception. The OFF Festival provides, as asserted by its participants, access to little-known 


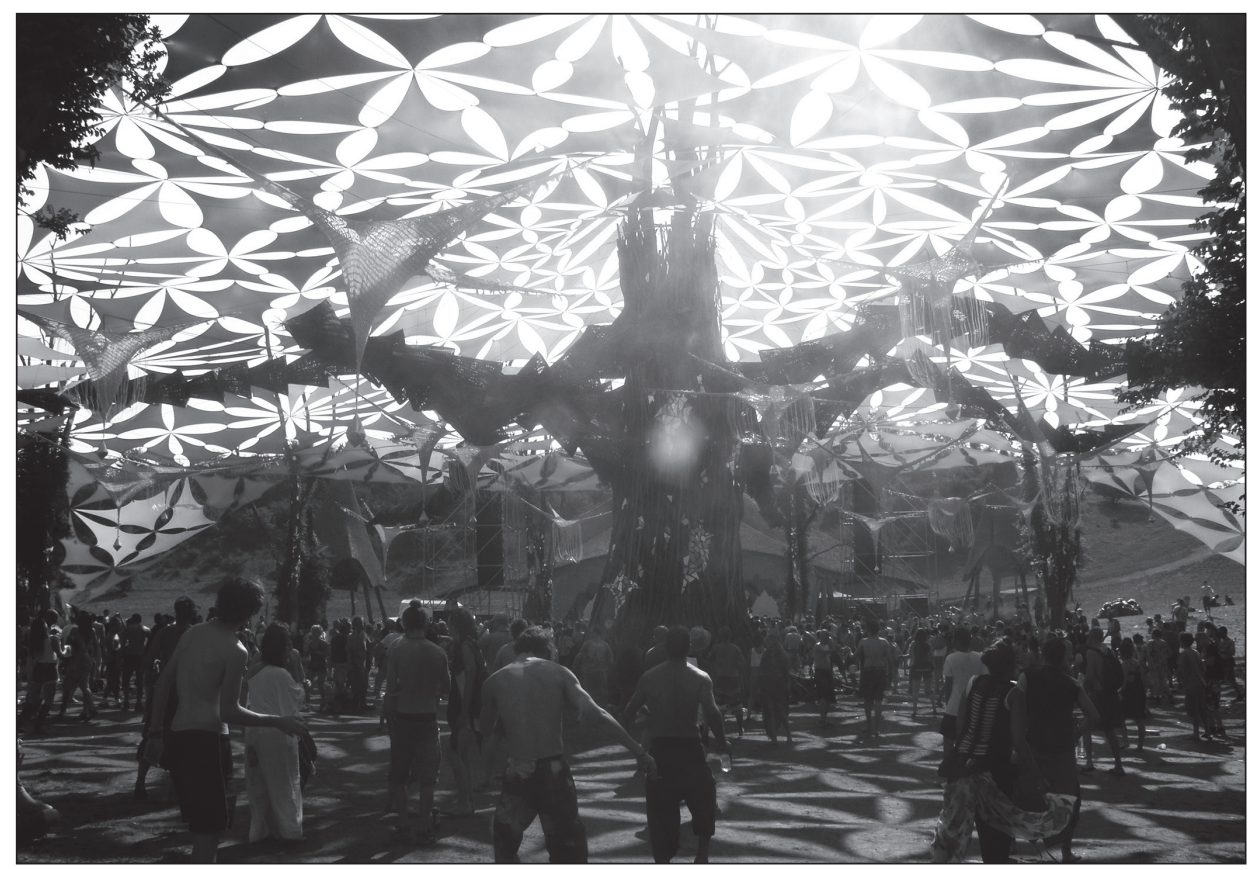

Figure 5. O.Z.O.R.A. Festival, Ozora, Hungary. (Photo by: Waldemar Kuligowski, August 2015)

music bands, representing niche genres. Participation in this festival gives a sense of participation in an exclusive, even elitist event. In the program of 10th edition of the festival, the opening text by the organizers, entitled "Ten years of swimming upstream", reads thus: "Every edition is a celebration of alternative music (...). It's a celebration of freedom, imagination and individualism." It is often stressed that the music played at OFF is "difficult" and requires that one be competent enough to receive its message. We can say that the dominant attitude here is a certain type of musical snobbery (Figure 6). "These are not random people - said one of the participants - they came here to listen to ambitious music." It is linked to a popular attitude of listening to music alone, yet surrounded by a crowd of people. Freedom at the OFF Festival is associated with three values: a refined music, personal experience of the music and the organization of the festival, which ensures the impression of intimacy. The word "OFF" in the name of the festival is therefore regarded as its symbolic essence, both in terms of music content, as well as to the audience, which self-defines itself in this way.

In the context of these two festivals, the O.Z.O.R.A. Festival creates an event of the most complete character. Organizers refer directly to the tradition of New Age and hippie ideology. They use slogans, such as "sound of universe", "Goa state of mind", "redefining the ancient tribal ritual for the 21st century" (the titles of articles from "The Ozorian Prophet"). There is a gate leading to a separate area of the festival which says "Welcome to Paradise". According to these slogans, the participants of the festival associate freedom with a state of mind and spirit, which is expressed through many hours of uninhibited dancing, the possibility of meditation, taking psychedelic drugs and a particular way of dressing, and more generally, a lifestyle (the festival area is open to the public for 


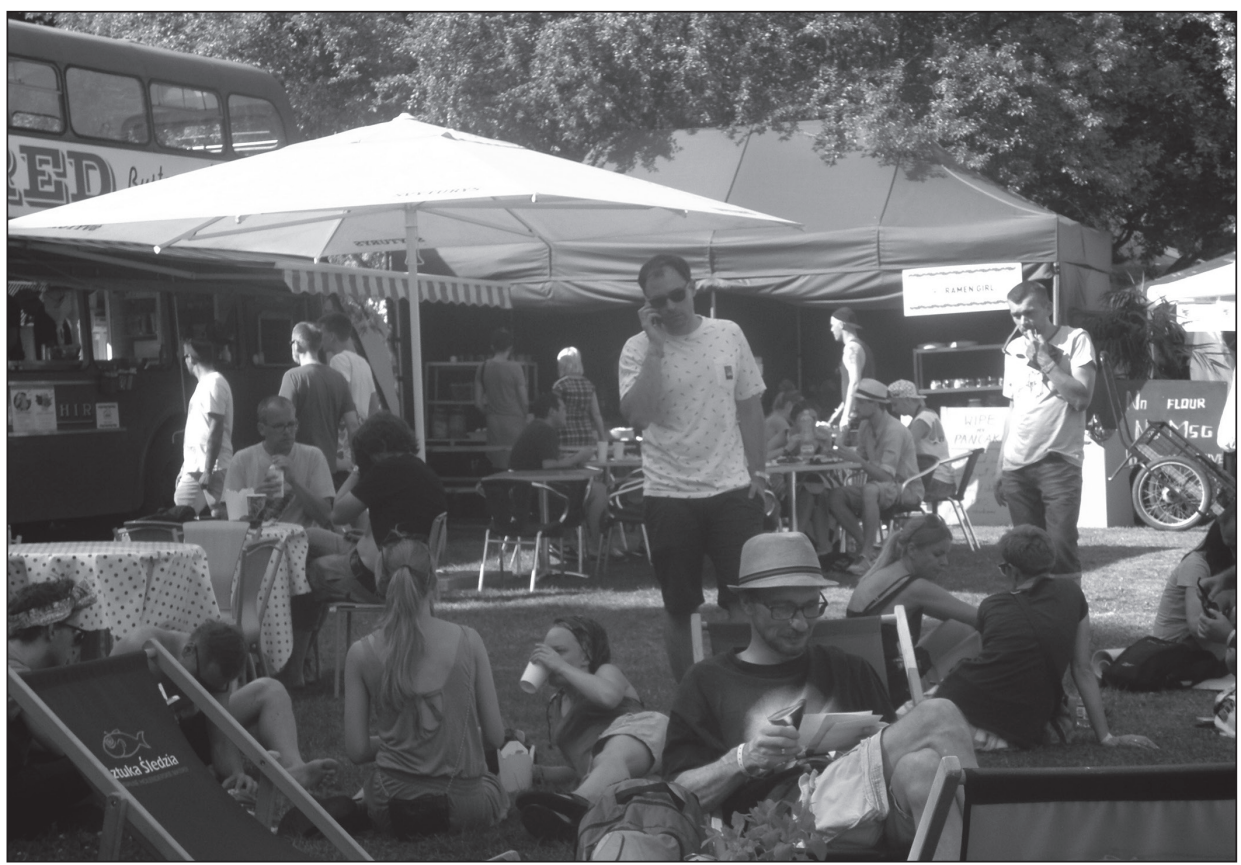

Figure 6. OFF Festival, Katowice, Poland. (Photo by: Waldemar Kuligowski, August 2015)

several weeks, during which many people lead a normal life there, often with family and children). Participants often say that O.Z.O.R.A. is a "festival with the message". Depending on the given individuals' country of origin, the message is associated with Hungary (Viktor Orbán's criticized governments) or with the modern world as such.

The main motivations for participation in music festivals involve, therefore, the need for rest and relaxation as well as the search for an area of freedom - political, artistic or spiritual. The audience at each of the three festivals described above was specifically motivated by these reasons, although to varying degrees. There is no doubt that the organizers of the Jarocin, OFF and O.Z.O.R.A. festivals have partly created these needs. Evoking the legend of the libertarian and sub-cultural festival (Jarocin), creating the image of a festival with difficult music for a competent public (Katowice), and promoting the festival as a psychedelic "state of mind" (Ozora) are the key strategies of the organizers. They have both an ideological and a marketing dimension. The map of European festivals is currently so dense that every organizer is forced to seek out a new formula that will allow them to differentiate themselves from the competition. In this aspect, there is often a conflict between authenticity and commercialism. The audience of the festivals in Jarocin, Katowice and Ozora has accepted the strategies of the organizers, treating them as authentic.

This does not mean that it is impossible to find values other than relaxation and freedom among the motivations of the participants attending the festivals. Many people openly talk about the festival as an opportunity to have fun, often involving alcohol or drugs, or as an opportunity for casual sex. Here are two common opinions (the second of which contains quite an original image): 
"For me it's rest, although it's common knowledge that you drink from morning to morning. Yesterday we finished about half past seven in the morning. But we're alive, we're breathing. There's a group of friends, it's fun, and that's what it's about. We have recharged in safe company, without aggression, completely relaxed. We came here to rest." (Jajco, 48 years old, Jarocin)

"To feel the festival, you have to wake up in a tent at eight in the morning, you have to feel the stench of the porta-potty, you have to feel the dust and sand in your teeth, and the general fatigue and several-day intoxication. That's how real rock ' $n$ ' rollers do it, real to the bone. I know what I'm saying. They should create a festival-scented Christmas tree air freshener for cars." (Rafał, 42 years old, Jarocin)

\section{CONCLUSION}

Do the above motives of music festival participants allow them to be considered a realization of Roger Caillois' holiday? In my opinion - in terms of the attitudes of their audiences - festivals can indeed be considered holidays, as defined by Caillois'. Firstly, the festival is a holiday at the level of the description of practices. A holiday is, as Caillois remarked, a collective event full of noise, shouting, and spontaneous gestures. Modern festivals are no different. The dominant practice there is to be among an enthusiastic crowd, crossing the norms of behavior, the desire to "use", both in terms of consumption and emotion. The experience of a "collective vertigo" is expressed during festivals in ecstatic, sometimes hours-long dancing sessions. Elation is often accompanied by the consumption of alcohol and other drugs. What people look for at festivals is the freedom of manners, allowing for the acceptance of "dietary and sexual sacrilege" and various "contrary acts". Binge drinking, drug use, ecstatic dancing till one loses strength, stylized outfits and hairstyles, casual sex and the atmosphere of enthusiasm and elation - "That is the very law of festival" (CAILLOIS 2001:97-98). The rules of the festival are contrary to the rules of everyday life.

Secondly, the festival is a holiday at the level of the description of values. As I indicated, many participants treat their attendance at festivals as detachment from everyday life. This creates a sense of continuum: from being on vacation, through leisure time, to experiencing freedom in the political, artistic, and spiritual dimensions. Festival freedom is seen as a medium for strength and energy recovery, a free expression of one's identity, views and lifestyle. The values associated with participation in the festival are treated as unique and impossible to realize elsewhere.

At both the level of practices and values, contemporary music festivals exhibit many similarities to Caillois' Théorie de la fête. As Caillois emphasized, holidays/festivals "constitute an interruption in the obligation to work, a release from the limitations and servitude of the human condition.. the moment in which the myth or dream comes alive" (2001:126). Although they use different words, festival participants perceive contemporary music festivals in the same way. It is therefore possible and useful to update the concept of the French anthropologist as it allows for the placement of the phenomenon of the festival in a different context. Of course, there is a fundamental, typological difference between tribal societies and their holidays and festivals. In my opinion, however, the "possibility of festival", in Caillois' terms, today is provided first 
and foremost by music festivals. For thousands of people, the festival is a place of rest, fun, elation, belonging to a community, or even freedom at different levels. For many participants, it is a holiday in its purest form; a festival, the subject of which is music, but the purpose of which is mental rest. It is also reasonable to use the modern concept of myth in relation to festivals: in Jarocin, it is a libertarian myth formed in the past; in Katowice, the myth of artistic value, while in Ozora, the myth of free existence.

In this context, the concept of festivalization mentioned above requires redefinition. In the analyzed cases, festivalization is not reduced to specific, collective forms of consumption. It also means the possibility to create specific space-times of rest and freedom. In other words, festivalization is a possibility of festival. The organization of music festivals is consistent with the philosophy of fragmented culture, in which different groups can express their identities and practice their lifestyles, even if such a possibility lasts only for a few days. Finally, we find in it yet another feature of Caillois' holiday: festival paroxysm; ecstasy and madness are predictable, short-term and reversible. From the festival, one must return to everyday life.

\section{REFERENCES CITED}

BAuman, Zygmunt

1993 Postmodern Ethics. Oxford: Blackwell.

Burke, Peter

2009 Popular Culture in Early Modern Europe. New York: Routledge.

CAILlois, Roger

2001a Man, Play and Games. Urbana and Chicago: University of Illinois Press.

2001b Man and the Sacred. Urbana and Chicago: University of Illinois Press.

Clifford, James

1986 Introduction. Partial Truths. In J. Clifford - MArcus, G. E. (eds) Writing Culture. The Poetics and Politics of Ethnography, 1-26. Berkeley: University of California Press.

DuRKHEIM, Émile

1912 Les formes élémentaires de la vie religieuse. Le système totémique en Australie. Paris: Librairie Félix Alcan.

Duvignaud, Jean

1976 Festivals: A Sociological Approach. Cultures 3(1):13-22.

EISEnHAuer, Simone, - AdAir, Daryl - TaYlor, Tracy

2014 Neoliberalism and Mega-Event Security Legacies: The 2010 FIFA World Cup, Cape Town, South Africa. International Journal of Event Management Research 8(1):35-59.

Eliade, Mircea

1957 Le sacré et le profane. Paris: Gallimard.

FALASSI, Alessandro

1987 Festival: Definition and Morphology. In Falassi, A. (ed) Time Out of Time: Essays on the Festival, 1-10, Albuquerque: University of New Mexico Press. 
FebVRe, Lucien

1951 Review of Roger Caillois "L'Homme et le Sacré" (compte rendu). Annales. Économies, Sociétés, Civilisations 6(3):409-410.

FRITH, Simon

1998 Performing Rites. On the Value of Popular Music. Cambridge: Harvard University Press.

GELL, Alfred

1998 Art and Agency. An Anthropological Theory. Oxford: Clarendon Press.

Haussermann, Hartmut, - Siebel, Walter

1993 Die Politik der Festivalisierung und die Festivalisierung der Politik. Leviathan 13:7-31.

HerzFeld, Michael

1997 Cultural Intimacy. Social Poetics in the Nation-State. New York-London: Routledge.

Hollier, Denis

1979 Le Collège de Sociologie. Paris: Gallimard.

Johansson, Marjana - KociatKiEwicz, Jerzy

2011 City Festivals: Creativity and Control in Staged Urban Experiences. European Urban and Regional Studies 18:392-405.

KuLigowski, Waldemar

2004 Miłość na Zachodzie. Historia antropologiczna. Poznań: Wydawnictwo Naukowe UAM.

2014 Nationalism and Ethnicization of History in a Serbian Festival. Anthropos. International Review of Anthropology and Linguistics 109(1):249-259.

2015 Sentymentalizacja, topofilia i pokoleniowość. Jarocin re-study. Czas Kultury 4:32-42.

2016 Festivalizing Tradition. AFieldworker's Notes from the Guča Trumpet Festival (Serbia) and the Carnival of Santa Cruz de Tenerife (Spain). Lithuanian Ethnology: Studies in Social Anthropology and Ethnology. 16(25):35-54.

LAVILLE, Yann

2014 Festivalisation? Cahiers d'ethnomusicologie 27:11-25.

Lesiakowski, Krzysztof - Perzyna, Paweł - ToBorek, Tomasz

2004 Jarocin w obiektywie bezpieki. Warszawa: Instytut Pamięci Narodowej.

MALCZYK, Tomasz

2010 Nysa Science Festival as International Instrument of Knowledge Diffusion in Regional Economic and Non Economic Network Organizations. Nysa: The School of Higher Vocational Education.

Mausss, Marcel

1906 Essai sur les variations saisonnières des sociétés Eskimos. Étude de morphologie sociale. L'Année Sociologique 9:39-132.

O'Grady, Alice

2013 Interrupting Flow: Researching Play, Performance and Immersion in Festival Scenes. Dancecult. Journal of Electronic Dance Music Culture. 5(1):18-38.

Richards, Greg - PALMER, Robert

2010 Eventful Cities. Cultural Management and Urban Revitalization. St. Louis: Butterworth-Heinemann. 
RONSTRÖM Owe

2011 Festivalisation: What a Festival Says - and Does. Reflections Over Festivals and Festivalisation. Sweden: Gotland University. https://uu.diva-portal.org/ smash/get/diva2:461099/FULLTEXT01.pdf (Accessed May 25, 2017).

St JoHn, Graham

2010 The Local Scenes and Global Culture of Psytrance. New York: Routledge

Steinbrinka, Malte - Heferburg, Christoph - Leyc, Astrid

2011 Festivalisation and Urban Renewal in the Global South: Socio-Spatial Consequences of the 2010 FIFA World Cup. South African Geographical Journal 93(1):15-28.

STEINER, George

1996 'A Festival Overture'. Lecture. Edinbourgh: University of Edinbourgh.

TAYLOR, Jodie

2014 Festivalizing Sexualities: Discourses of 'Pride', Counterdiscourses of 'Shame'. In BenNetT, Andy - TAYlor, Jodie - WoodwARD, Ian (eds) The Festivalization of Culture, 27-49, Aldershot: Ashgate.

TEDLOCK, Barbara

1992 The Beautiful and the Dangerous: Dialogues with the Zuni Indians. New York: Viking.

THOMPSON, James

2009 Performance Affects: Applied Theatre and the End of Effect. Basingstoke: Palgrave Macmillan.

TURner, Aaron

2000 Embodied Ethnography. Doing culture. Social Anthropology 8(1):51-60.

TURNER, Victor

1969 The Ritual Process: Structure and Anti-structure. Chicago: Aldine Publishing Co.

VAN AALST, Irina

2012 City Festivals and Urban Development: Does Place Matter? European Urban and Regional Studies 19:195-206.

VAN ELDEREN, P. Louis

1997 Suddenly One Summer: a Sociological Portrait of the Joensuu Festival. Joensuu: Joensuu University Press.

VAN GENNEP, Arnold

1960 The Rites of Passage. Chicago: University of Chicago Press. 
Waldemar Kuligowski is a professor at the Department of Ethnology and Cultural Anthropology at Adam Mickiewicz University in Poznań (UAM). Recently, he has been acting as a member two committees of the Polish Academy of Sciences: The Committee of Cultural Studies and The Committee of Ethnological Studies. He is also an editor-in-chief of "Czas Kultury" [Time of Culture], a Polish socio-cultural quarterly. He is a member on the editorial boards of the scientific journals: "Slavia Meridionalis" and "Historia i Kultura" [History and Culture]. He has conducted fieldwork in Poland, Germany, Uzbekistan, Spain, Serbia, Hungary, and Albania. His research interests focus on the theory of culture, reflexive ethnography, globalization, the anthropology of motorway and festivals and festivalization. 